\title{
Exploring High-Performance Work Systems for Sustainability in the Hotel Industry
}

\author{
Dianawati Suryaningtyas ${ }^{1}$, Dodi W. Irawanto ${ }^{2}$ \\ ${ }^{1}$ Faculty of Economy and Business, Kanjuruhan University, Malang, Indonesia \\ 2, Faculty of Economy and Business, Brawijaya University, Malang, Indonesia \\ 11diana.surya@unikama.ac.id;2dodi.wi@ub.ac.id
}

\begin{abstract}
High-Performance Work Systems have become highly important in a business competition in the last few decades.HPWS as a resource for sustainable competitive advantage. This paper aims to explore how high-performance work systems deliver sustainability of the organizations where disruption technology as the main factor of external challenges. A research paper is proposed in regards to this issue. A descriptive analysis as a statistical tool was used to analyze the data and mean as the measurement of the variable.The result reveals that HighPerformance Work Systems deliver a contribution to the role of achieving sustainability of the organizations through training which develops the flexible capability to adapt to external changes and challenges. This study is particularly useful for practitioners by identifying advantages of High-Performance Work Systems action for organizations and how it can be a resource of sustainable competitive advantage. This paper gives valuable reference to general managers as well as human resource managers to maintain High-Performance Work Systems in order to achieve sustainability of the organizations.
\end{abstract}

Keywords: High-Performance Work Systems, Sustainability, Disruption Technology, Hotel Industry

\section{Introduction}

Disruption technologyhas fostered the emergence of industrial revolution 4.0. Innovation in business into the digital era has given many difficult conditions for organizations. A business that built over many years must be adjusted and transformed into digitalization. Why organizations should respond to the coming new era? How do organizations start to react to this difficult conditions? The importance of this research paper is to help practitioners and executives find the answer to those questions and what the main factor that organizations must focus in order to maintain survival and build sustainability of their firms.

Since the last few decades, the growing research of examining the relationship between human resource management and the effect of organizational performance has been done by many researchers. Human resource management research which focuses on high-performance work systems has a positive impact on firm performance [1]. There has been continued debate among researchers in regard tothe different perceptions and arguments about the "black box" in the relationship between human resource management and organizational performance.Therefore, these differences stimulate a growing interest in furtherresearch linking human resource management system and firm performance [2]Recent studies of human resource management highlight the need for further progress of examining the mediating roles oforganizational 
capabilities or more specific dynamic capabilities between HPWS and organizational performance, such as human resource flexibility [3]Human resource management systems that enhance competencies, commitment, and employee productivity called High-Performance Work Systems (HPWS) [4]; [5]High- Performance Work Systems (HPWS) defined as a specific combination of human resource practices, work structures and processes that maximizes employee knowledge, skills, commitment, and flexibility [6] The term of HPWS itself has been difficult to get an agreed definition because the significant difference between the theoretical, empirical, and practical approach used by researchers, for instance: High Performance Work Practice (HPWP), High Commitment Management (HCM), High Involvement Management (HIM) [7]However, HCM and HIM are not equivalent to HPWS [8]

HPWS derived from a bundle of human resource management systems which include human resource policies, practice, and process and can be linked to outcomes at both employees and organizational levels [9]; [10]The significant aspect of HPWS definition is a bundle of systems and not an individual characteristic of the human resource. The key point of view for the firm success in the market nowadays is dominantly derived from a human resource of the firm, as human resources are one of the most important resources to generate competitive advantage of the firms [11]

[12]The concept of HPWS can be approached from the perspective of Resource-Based View (RBV) of the organization, which implies that a resource can be qualified as a source of competitive advantage as long as the resource is rare, hard to be imitated, and adds value to the organization[12] ; [13]According to this concept, Lado and Wilson [14]mentioned that sustainable competitive advantage can be achieved as long as human resource systems are able to develop specific competencies and capabilities of the organizations. Besides, it can also provide the organization with both increased fit and flexibility [15]HPWS indicates a system or a bundle of human resource practices which design to increase skills, commitment, and involvement so that employees can be of resource for sustainable competitive advantage [1]

Sustainability is increasingly a strategic issue for organizations to look for a competitive advantage. Sustainable competitive advantage refers to a benefit of firms or organizations that differentiating from their competitors and cannot be duplicated [16]. And it can be reached if a human resource of a firm or organizations become unique, rare, and difficult to imitate[17]; [13] as a result of creating values executed by Senior Human Resource Managers [18]According to Swiercz (1995), values can be shaped through firm performance resulted from the investment of a company on recruitment, training, and employee development. Sustainability can also be reached when organizations have a competitive advantage in the hospitality industry [1]; [18]In accordance with those previous research (Combs et al., 2006), HPWS through its indicators used in this research (training, salary system, evaluation system, and autonomy that relates to employee motivation) can be explored to deliver contribution of sustainability for the firms or organizations.

Organizations in hotel industry face a competitive and complex environment, where human resource management plays a critical role in this difficult conditions. As the product of the hotel industry is a service experience, organizations mostly depend on human resource capabilities to interact face to face with customers. According to Baum and Tracey, human resource management play a key role in service quality, satisfaction, and customer loyalty as a measurement of firm performance [19]; [20]In this context, HPWS is mostly needed in the hotel industry as the key role to face competitive and cope with the complex environment. Notwithstanding, research to investigate HPWS in the hotel industry as the key for competitive advantage is still rare. The objective of this research paper is to explore how HPWS can contribute sustainability of the organizations in the hotel industry where competitiveness is very tight and strong,particularly in facing the disruption technology and other external disturbances. 


\section{Method}

This research conducted within 3-star hotel industries in 2 towns in East Java Indonesia, found the population of the 3-star hotels and equivalent were 38 firms. The technique sampling method was purposive sampling. A questionnaire survey was administered to 76 General Managers and Human Resource Managers or the persons in charge of those positions. These respective respondents were persons who were responsible for developing their human resources. Each firm represented by two respondents and only 6 sets of questionnaires were not returned.

Descriptive analysis was a statistical tool used to analyze the 70 sets of returned questionnaires. High- Performance Work System used in this research has 4 indicators according to Combs et al. [1] consist of training, salary system, evaluation system, and autonomy that relates to employee motivation. Each indicator has 2 items accordingly. SPSS software was used to process the data. The result of validity and reliability tested were all valid and reliable. The scope and limitations of this study were that organization as unit analysis and small size of samples.

\section{Result And Discussion}

The questionnaires were processed using descriptive analysis with mean and standard deviation to describe the data. The result displayed in Table 1.

Table 1: Mean

\begin{tabular}{|c|c|c|}
\hline $\begin{array}{c}\text { High-Performance Work System } \\
\text { (HPWS) }\end{array}$ & Mean & $\begin{array}{l}\text { Std. } \\
\text { Dev. }\end{array}$ \\
\hline $\begin{array}{l}\text { Training } \\
\text { Training should be done in order to } \\
\text { follow external changes. } \\
\text { Training should be employed to } \\
\text { potential employees for career } \\
\text { development. }\end{array}$ & 4.01 & 0.84 \\
\hline $\begin{array}{l}\text { Salary System } \\
\text { Salary should be paid based on } \\
\text { experience/expertise. } \\
\text { Salary should be paid more for } \\
\text { employees who work in a team. }\end{array}$ & 4.13 & 0.88 \\
\hline $\begin{array}{l}\text { Evaluation System } \\
\text { Performance evaluation is executed } \\
\text { at least once a year. } \\
\text { Rewards are given to employees } \\
\text { with outstanding performance. }\end{array}$ & $\begin{array}{l}4.41 \\
4.44\end{array}$ & 0.65 \\
\hline $\begin{array}{l}\text { The autonomy that relates to } \\
\text { employee motivation } \\
\text { Employees are given authority for } \\
\text { making the decision to finalize their } \\
\text { jobs } \\
\text { Employees are given opportunities } \\
\text { to create innovation in their jobs. }\end{array}$ & 4.03 & $\begin{array}{l}0.68 \\
0.69\end{array}$ \\
\hline
\end{tabular}

Result in Table 1 showed that all the mean values were above its standard deviations. It demonstrated that all the data did not contain outliers. The highest mean value was 4.56. It indicated that respondents chosen an item of training should be done in order to follow external changes was the most preferred of all respondents. On the contrary, the lowest mean value was 
3.57. It indicated that respondents chosen an item of salary should be paid more for employees who work in a team was the lowest preference of all respondents.

The most preference of respondents to choose an item of training should be done in order to follow external changes means that most respondents agreed that this kind of training should be done. It reveals that respondents realized the organizations need the capability of continues adaptation in order to follow the changes in external environments. Otherwise, the organizations will no longer survive. This finding indicates that flexible capability is needed and important to face continues changes and cope with external environments. HPWS which focus on training to enhance employeecapabilities to continuously adaptable with external changes and challenges. Flexible capability drives organizations to achieve sustainability. This result supportsDelery's statement that HPWS can also provide the organization with both increased fit and flexibility ([15]

In addition, values of human resource can be created and shaped through training of employees (Swiercz,1995)responsible bySenior Human Resouce Manager [18] to become unique, rare and difficult to imitate and substitute [12]; [13] and at the end will impact to organizational performance. This results also supports Lado and Wilson [14]research that sustainable competitive advantage can be reached if organizations develop specific competencies and capabilities. In this context of research, specific competencies are the ability to adapt to external changes and when it is done continuously and consequently will foster the sustainability of the organizations.

Sustainable competitive advantage is also needed in the hotel industry. As this research was conducted in the hotel industry, the result also supports Combs and Suryaningtyas[1]; [18]

The lowest preference of respondents to choose an item of salary should be paid more for employees who work in a team. It means that only a few respondents agreed with this statement. This result reveals that employees who work independently should receive the same level of salaries as employees who work in a team. From this point of view, Human Resource Managers should create and socialize the importance and advantages of working in a team. And when it works, they should appreciate the team by giving higher salaries respectively, based on employee contributions to the organizations.

\section{Conclusions}

Overall, the conclusion of this research is that HPWS can foster organizations to achieve sustainability through training that develops flexible capability and shaping values to employeesso that organizations have the capability to adapt with external changes and challenges, such as disruptive technology as an impact of digital innovation.

The implication for General Manager and Human Resource Manager is that they should focus on developing HPWS including building teamwork which contribute to the key role in achieving sustainability of the organizations. Further research should be done in different kind of businesses with and larger sample size.

\section{References}

[1] J. Combs, Y. Liu, A. an. K. Hall, and D., "How much do high-performance work practices matter? A meta-analysis of their effects on organizational performance," Personnel Psychology, vol. 59, pp. 501-28, 2006.

[2] M. A. an. B. Huselid and B.E., Bridging micro and macro domains: workforce differentiation and strategic human resource management,Journa lof Management, Vol.37No.2,pp.421-428. 2010.

[3] R.-P. Beltrán-Martín, Escrig-Tena, and BouLlusar, "Human Resource Flexibility as a mediating variable between high-performance work systems and performance," Journal of Management, vol. 34, pp. 1009-1043, 2008. 
[4] E. an. B. Appelbaum and P., "High-performance work systems and labor market structures," in Sourcebook of Labor Markets, I. B. and A. L. Kalleberg, Ed. New York: Kluwer Academic/Plenum Publishers, 2001, pp. 271-94.

[5] D. Datta, J. Guthrie, and P. Wright, "Human resource management and labor productivity: Does industry matter?," Academy of Management Journal, vol. 48, no. 1, pp. 135-145, 2005.

[6] G. Bohlander and S. Snell, Managing human resources. USA: Thomson Learning, Inc.v, 2007.

[7] P. an. M. Boxall and K., "High-involvement work process, work intensification, and employee well-being," Work, Employment and Society, vol. 28, pp. 963-984, 2014.

[8] P. an. M. Boxall and K., "Research and theory on high-performance work systems: progressing the high-involvement stream," Human Resource Management Journal, vol. Vol., pp. 3-23, 2009.

[9] K. Cafferkey and T. Dundon, "Explaining the black box: HPWS and organizational climate," Personal Review, vol. 44, pp. 666-668, 2015.

[10] K. Monks, G. Kelly, E. Conway, P. Flood, K. Truss, and E. Hannon, "Understanding how HR systemswork: The role of HR philosophy and HR processes.Human Resource," Management Journals, vol. 23, pp. 379-395, 2013.

[11] B. Zhang and J. L. Morris, "High-performance work systems and organizational performance: testing the mediation role of employee outcomes using evidence from RR China," The International Journal of Human Resource Management, vol. 25, pp. 68-90, 2014.

[12] J. B. Barney, "Firm resources and sustained competitive advantage," Journal of Management, vol. 17, no. 1, pp. 99-120, 1991.

[13] P. Boxall, "The Strategic HRM debate and the resource-based view of the firm," Human Resource Management Journal, vol. 6, pp. 59-75, 1996.

[14] A. A. Lado and M. C. and Wilson, "Human ResourceSystems and Sustained Competitive Advantage: ACompetency-Based Perspective, Academy ofManagement," Review, vol. 19, no. 4, pp. 699-727, 1994.

[15] J. E. Delery, "Issues of fit in strategic human resource management: Implication for," Research. Human Resource Management Review, vol. 8, no. 289 - 310, 1998.

[16] K. Macky and G. and Johnson, Managing HumanResourcesin New ZealandAuck-land:McGraw-Hill, 2nd ed. 2003.

[17] J. B. Barney and P. M. and Wright, "On becoming a strategic partner: the role ofhuman resources in gaining competitive advantage," Human Resource Manage-ment, vol. 37, no. 1, pp. 31-46, 1998.

[18] D. Suryaningtyas and Asna, "The Strategic Roles ofHuman Resource Manager to Achieve Competitive Advantage in the Hospitality Industry," Journal of Applied Management, vol. 15, no. 1, Mar. 2017.

[19] T. Baum, Human resources in tourism: still waiting for change? A 2015 reprise. Tourism Management,Vol.50,pp.204-212, 2015.

[20] J. Tracey, "A review of human resources management research: the past 10 years and implications for moving forward",International," Journal of Contemporary Hospitality Management, vol. 26, no. 5, pp. 679-705, 2014. 
